\title{
Interferon- $\alpha$-Mediated Activation of T Cells from Healthy and HIV-Infected Individuals Is Suppressed by $\Delta^{9}$-Tetrahydrocannabino|[
}

\author{
Joseph E. Henriquez, Michael D. Rizzo, Robert B. Crawford, Peter Gulick, \\ and Norbert E. Kaminski
}

Departments of Pharmacology and Toxicology (J.E.H., N.E.K.), Cell and Molecular Biology (M.D.R.), and Osteopathic Medicine (P.G.), and Institute for Integrative Toxicology (J.E.H., M.D.R., R.B.C., N.E.K.), Michigan State University, East Lansing, Michigan

Received May 1, 2018; accepted June 28, 2018

\begin{abstract}
Patients with HIV routinely use medicinal cannabinoids to treat neuropathic pain, anxiety, and human immunodeficiency virus (HIV)-associated wasting. However, $\Delta^{9}$-tetrahydrocannabinol (THC), the primary psychoactive cannabinoid in cannabis, suppresses T-cell function and secretion of interferons, both critically important in the antiviral immune response. Interferon- $\alpha$ (IFN $\alpha$ ), a key cytokine in T-cell activation and peripheral control of HIV infection, can potentiate responsiveness to interleukin-7 (IL-7), a crucial homeostatic cytokine for peripheral T-cell maintenance. The objective of this investigation was to compare the response of T cells to stimulation by IFN $\alpha$ and IL-7 in T cells from healthy and $\mathrm{HIV}^{+}$donors in the absence and presence of THC. To compare T-cell responses between healthy and $\mathrm{HIV}^{+}$ donors signaling through IFN $\alpha$ receptor, IFN $\alpha$-induced expression of IL-7 $\alpha$ receptor (IL-7R $\alpha$ ), cognate signaling through IL-7R,
\end{abstract}

and on IL-7-mediated T-cell proliferation were measured by flow cytometry and real-time quantitative polymerase chain reaction. $\mathrm{CD}^{+}{ }^{+} \mathrm{T}$ cells from $\mathrm{HIV}^{+}$donors showed a diminished response to IFN $\alpha$-induced phosphorylated signal transducer and activator of transcription- 1 activation compared with $\mathrm{CD}^{+} \mathrm{T}$ cells from healthy donors, whereas $\mathrm{CD}^{+}{ }^{+} \mathrm{T}$ cells from $\mathrm{HIV}^{+}$donors and healthy donors were comparable. Treatment with IFN $\alpha$ promoted IL-7R expression and potentiated IL-7-induced STAT5 phosphorylation to augment IL-7-mediated proliferation by $\mathrm{T}$ cells from healthy and $\mathrm{HIV}^{+}$donors. Finally, $\mathrm{HIV}^{+}$donors exhibited reduced sensitivity to THC-mediated suppression by IFN $\alpha$ - and IL-7-mediated stimulation compared with healthy donors. These results further support THC as being immune suppressive while identifying putatively beneficial aspects of cannabinoid-based therapies in $\mathrm{HIV}^{+}$patients.

\section{Introduction}

Approximately 37 million people globally are infected with human immunodeficiency virus (HIV) (Karim, 2017), of whom 1.1 million reside in the United States (Hess et al., 2017). CD4 ${ }^{+}$ T-cell leukocytopenia is a hallmark of HIV infection, with $\mathrm{CD} 4^{+}$ $\mathrm{T}$ cells being a primary cellular target for HIV (Dragic et al., 1996; Sousa et al., 2002). The perturbation of $\mathrm{CD} 4^{+} \mathrm{T}$ cells causes a loss of adaptive immune integrity, including loss of cytotoxic T-lymphocyte (CD8 ${ }^{+}$T-cell) function (Roederer et al., 1995), culminating in AIDS (Koot et al., 1993). Since the mid-1990s, the standard of care after HIV diagnosis has been antiretroviral therapy (ART) (Autran et al., 1997; Iacob et al., 2017). ART facilitates $\mathrm{CD} 4^{+}$T-cell restoration and, by extension, CD8 ${ }^{+}$T-cell restoration (Oxenius et al., 2000). However,

All funds for these studies were supplied through the National Institute on Drug Abuse Grants DA007908 and DA047180; and a National Institute of Environmental Health Sciences Training Grant T32-ES007255. No potential conflicts of interest relevant to this article are reported.

https://doi.org/10.1124/jpet.118.250308.

S This article has supplemental material available at jpet.aspetjournals.org.
15\%-20\% of patients with HIV continue to have T-cell deficiencies despite undergoing successful ART (Kelley et al., 2009; Serrano-Villar et al., 2014).

One reported T-cell deficiency in patients with HIV exhibiting a low $\mathrm{CD} 4^{+} \mathrm{T}$-cell nadir is reduced expression of interleukin-7 (IL-7) receptor (IL-7R) (MacPherson et al., 2001; Nguyen et al., 2016; Hartling et al., 2017). IL-7 is a crucial cytokine for T-cell integrity as it drives both differentiation and peripheral maintenance of T cells (Tan et al., 2001). Likewise, IL-7 enhances the expansion of T cells from $\mathrm{HIV}^{+}$donors (Bazdar and Sieg, 2007; Levy et al., 2009; Sereti et al., 2009). Clinically, the use of IL-7 in patients with HIV reversed T-cell leukocytopenia and restored gut lumen integrity (i.e., leaky-gut syndrome) (Sereti et al., 2014). The mechanisms underlying IL-7R expression deficiency in HIV-infected T cells is poorly understood, but is correlated with the phenomenon termed "T-cell exhaustion," which is associated with chronic and extensive antigenic stimulation (Lang et al., 2005).

IL-7R expression is tightly regulated, with type 1 interferons playing a critical role in that regulation through a type

ABBREVIATIONS: ART, antiretroviral therapy; C-RPMI, complete RPMI; DI, division index; HIV, human immunodeficiency virus; IFN, interferon; IFNAR, interferon- $\alpha$ receptor; IL-7, interleukin-7; IL-7R, interleukin-7 receptor; MACS, magnetic activated cell sorting; MMHC, Mid-Michigan HIV Consortium; PBS, phosphate-buffered saline; PCR, polymerase chain reaction; pDC, plasmacytoid dendritic cell; pSTAT, phosphorylated signal transducer and activator of transcription; THC, $\Delta^{9}$-tetrahydrocannabinol; Treg, T regulatory; VC, vehicle control. 
1 interferon-inducible promoter region called an interferon (IFN)-sensitive responsible element (Mazzucchelli and Durum, 2007). Type 1 IFNs are composed of IFN $\alpha$ and IFN $\beta$ and possess antiviral activity (García-Sastre and Biron, 2006). Plasmacytoid dendritic cells ( $\mathrm{pDCs}$ ) are the primary source of IFN $\alpha$ secretion (Colonna et al., 2004) and have a direct influence on maintaining T-cell integrity during HIV infection. Typically, the circulating numbers of $\mathrm{pDCs}$ and $\mathrm{CD} 4^{+} \mathrm{T}$ cells are correlated in a positive manner (Donaghy et al., 2001). During chronic HIV infection, there is a reduction of $\mathrm{pDC}$ number and function, resulting in a decreased capacity to produce IFN $\alpha$ (Chehimi et al., 2002). IFN $\alpha$ has also been shown to suppress HIV expansion (Poli et al., 1989) and provided protection for $\mathrm{CD}^{+} \mathrm{T}$ cells from $\mathrm{HIV}$ mediated depletion in a humanized mouse model (Lapenta et al., 1999). Furthermore, pDCs promoted T-cell activation and protection against certain viral infections when using an Fc-fused IL-7 (Kang et al., 2017).

In addition to the complications arising from chronic HIV infection, patients with HIV routinely use medicinal cannabinoids to treat HIV-associated wasting, as an appetite stimulant; and neuropathic pain, from the use of some HIV reverse transcriptase inhibitors as part of ART regimens; and generally reduce anxiety (Abrams, 2000; Prentiss et al., 2004; Haney et al., 2007; Ellis et al., 2009). The primary psychoactive cannabinoid in cannabis, $\Delta^{9}$-tetrahydrocannabinol (THC), and synthetic THC, like dronabinol (i.e., marinol), exhibit potent anti-inflammatory activity and are also immunosuppressive (Klein et al., 1998; Tanasescu and Constantinescu, 2010). It is well established that THC can suppress T-cell responses to viral infections (Reiss, 2010; Eisenstein and Meissler, 2015), including HIV (Roth et al., 2005). Additionally, pDC secretion of IFN $\alpha$ is acutely sensitive to THCmediated suppression, and pDCs from $\mathrm{HIV}^{+}$donors show increased sensitivity to THC-mediated suppression than pDCs from healthy donors (Henriquez et al., 2017).

The objective of this investigation was to compare the response of T cells to stimulation by IFN $\alpha$ and IL-7 in T cells from healthy and $\mathrm{HIV}^{+}$donors in the absence and presence of THC. Specifically, studies were conducted to determine whether in vitro stimulation of T cells by $\operatorname{IFN} \alpha$ would drive the expression of IL-7R $\alpha$, thereby potentiating IL-7-mediated signaling and proliferation. Furthermore, the effect of THC on the stimulation of T cells by IFN $\alpha$ and IL-7 was evaluated. Last, the responses to IFN $\alpha$ and IL-7, in the absence and presence of THC in $\mathrm{T}$ cells from healthy and $\mathrm{HIV}^{+}$donors, were compared.

\section{Materials and Methods}

Peripheral Blood Mononuclear Cell Isolation and Cell Identification. Leukocyte packs were purchased from the Gulf Coast Regional Blood Center (Houston, TX). Blood was diluted with Gibco Hanks' balanced salt solution from Thermo Fisher Scientific (Waltham, MA) and layered on Ficoll Paque Plus (GE Healthcare Life Sciences, Pittsburgh, PA) in SepMate tubes by StemCell Technologies (Vancouver, BC, Canada). Leukocytes were resuspended in Gibco complete RPMI (C-RPMI) media from Thermo Fisher Scientific containing 5\% Human AB Serum (Sigma-Aldrich, St. Louis, MO), $1 \%$ Penicillin-Streptomycin (Thermo Fisher Scientific), and $0.1 \%$ $\beta$-mercaptoethanol. $\mathrm{T}$ cells were identified using antibodies by BioLegend (San Diego, CA) as $\mathrm{CD}^{+}$cells and as either $\mathrm{CD}^{+}$or $\mathrm{CD}^{+}$. Memory cells were identified as $\mathrm{CD}^{2} 5 \mathrm{RO}^{+}$and nonmemory cells were identified as $\mathrm{CD}_{4} 5 \mathrm{RO}^{-}$
T-Cell Purification by Magnetic Activated Cell Sorting. T cells were isolated using magnetic activated cell sorting (MACS) CD3-T-cell isolation kits from BioLegend. In short, after peripheral blood mononuclear cell (PBMC) isolation, the cell concentration was determined using a Coulter Particle-Counter (Beckman-Coulter Inc., Brea, CA), and the appropriate volume of non-T-cell antibody cocktail was incubated with PBMCs followed by washing with MACS buffer $[1 \times$ phosphate-buffered saline (PBS), $0.5 \%$ bovine serum albumin, and $2 \mathrm{mM}$ EDTA] and incubation with magnetic beads. Labeled PBMCs were then passed through a MACS magnet, and T cells were collected in the flow through.

Treatment with Cannabinoids or Vehicle Control. THC was supplied by the National Institute on Drug Abuse. Purified T cells or whole PBMCs were treated with either THC or vehicle control (VC; $0.03 \%$ ethanol) prepared in C-RPMI medium. Cells were incubated at $37^{\circ} \mathrm{C}$ and $5 \% \mathrm{CO}_{2}$ for 30 minutes before being stimulated (below).

Stimulation of T Cells. After treatment with THC or VC, PBMCs or isolated $\mathrm{T}$ cells were stimulated as follows: 1) to measure the phosphorylation of STAT1, cells were stimulated with $100 \mathrm{U} / \mathrm{ml}$ universal IFN $\alpha$ (PBL Assay Science, Piscataway, NJ) for 30 minutes before harvesting for phospho-protein detection (below); 2) to measure IFN $\alpha$-induced IL-7R $\alpha$ mRNA and protein expression, cells were treated with $100 \mathrm{U} / \mathrm{ml}$ IFN $\alpha$ for 48 hours before harvesting and measurement of respective endpoints (below); 3) IL-7-induced phosphorylation of STAT5 on day 0 or 48 hours after IFN $\alpha$ stimulation $(100 \mathrm{U} / \mathrm{ml})$ was measured by stimulating cells with $10 \mathrm{ng} / \mathrm{ml} \mathrm{IL-7} \mathrm{for}$ 15 minutes before harvesting for phospho-protein detection (below); and 4) for measuring IL-7-augmented proliferation of T cells (below), cells were stimulated with $100 \mathrm{U} / \mathrm{ml}$ IFN $\alpha, 2.5 \mu \mathrm{g} / \mathrm{ml}$ mouse antihuman CD3 antibody (BioLegend), and $2.5 \mu \mathrm{g} / \mathrm{ml}$ mouse antihuman CD28 antibody for 48 hours followed by stimulation with $10 \mathrm{ng} / \mathrm{ml} \mathrm{IL-7}$ or VC (sterile endotoxin-free water; InvivoGen, San Diego, CA), and cells were incubated for another 48 hours before harvesting.

Gene Expression Analysis. RNA was isolated using RNeasy Kits (Qiagen, Hilden, Germany) per the manufacturer instructions. Briefly, $\mathrm{T}$ cells were lysed using lysing buffer containing $\beta$-mercaptoethanol and stored at $-20^{\circ} \mathrm{C}$. Lysates were purified and treated with DNAse from an ST Total RNA Isolation Kit (Promega, Madison, WI). RNA concentrations were determined by Nanodrop (Thermo Fisher Scientific). Reverse-transcription polymerase chain reaction (PCR) was performed using a High Capacity cDNA Reverse Transcription Kit (Applied Biosystems, Foster City, CA). cDNA was stored at $-80^{\circ} \mathrm{C}$. Gene analysis was determined by real-time quantitative PCR using Life Technologies TaqMan Probes for IL-7R $\alpha$ [Hs00902334_m1; Thermo Fisher Scientific (through Compendia Bioscience, Ann Arbor, MI)] with $18 \mathrm{~S}$ ribosomal RNA as the loading control.

Phospho-Protein and IL-7R $\boldsymbol{\alpha}$ Detection. PBMCs were washed and $\mathrm{T}$ cells were stained as described above. Phosphorylated signal transducer and activator of transcription (pSTAT) 1 and pSTAT5 levels were determined using Phosflow antibodies and the harsh detergent method by BD Biosciences (San Jose, CA). In brief, cells were fixed using BD Biosciences Cytofix buffer for 10 minutes at $37^{\circ} \mathrm{C}$, permeabilized with $1 \times$ BD Phosflow Perm Buffer IV, stained for 1 hour under continuous motion in BD FACS Buffer (1× PBS, $1 \%$ bovine serum albumin, and $0.1 \%$ sodium azide) containing $7 \%$ Human AB Serum (Sigma-Aldrich), washed once with $0.5 \times$ BD Phosflow Perm Buffer, washed twice with BD FACS Buffer, and then immediately analyzed by flow cytometry. IL-7R $\alpha$ surface expression was determined by surface staining with mouse antihuman antibodies (BioLegend).

Detection of T-Cell Proliferation. Prior to activation (above), PBMCs were treated with violet CellTrace dye (Thermo Fisher Scientific). In brief, the dye was resuspended in dimethylsulfoxide and diluted in warm sterile PBS (0.02\% dimethylsulfoxide). PBMCs were incubated in the PBS/dye mixture at $37^{\circ} \mathrm{C}$ for 20 minutes and washed with C-RPMI medium. Cells were then centrifuged, washed with RPMI, and resuspended in C-RPMI before stimulation (above). T-cell proliferation for all T-cell populations was determined by dye dilution and presented as the division index (DI), which was generated 
by the FlowJo version 10 (FlowJo, LLC, Ashland, OR) proliferation tool. Specifically, the DI is the average number of cell divisions that a cell in the original population has undergone and includes all cells in the population.

HIV $^{+}$Donor Recruitment and Data Management. $\mathrm{HIV}^{+}$ donors voluntarily enrolled via the Mid-Michigan HIV Consortium (MMHC) under the Institutional Review Board-approved protocol (Institutional Review Board protocol no. 11-202) and into the MMHC Registry. $\mathrm{HIV}^{+}$donors were males between the ages of 31 and 71 years, with an average age of 54.4 years, who had $\mathrm{CD}^{+}$counts above 500 counts/ml blood, CD4/CD8 ratios $>1$, did not use medicinal cannabinoids, had HIV viral burdens below the detectable limit $(<5$ HIV mRNA copies/ml blood), were not coinfected with any strain of hepatitis, and were recruited from clinics attended by author P.G. The status of medicinal cannabinoid use was determined by self-reporting and was verified via plasma detection of THC metabolites using the THC ELISA (enzyme-linked immunosorbent assay) Forensic Kit (Neogen Corporation, Lansing, MI). $\mathrm{HIV}^{+}$donors received the standard of care and were not asked to change any lifestyle habits to participate. All subject, questionnaire, and abstracted medical record data of the MMHC are managed using the Research Electronic Data Capture (REDCap) (Vanderbilt University, Nashville, TN), which supports 21 Code of Federal Regulations Part 11 compliance for clinical research and trials data and Health Insurance Portability and Accountability Act of 1996 guidelines.

Data Analysis. Prism 5.0 by GraphPad Software, Inc. (La Jolla, $\mathrm{CA}$ ) was used for all data analyses. Where appropriate, samples were normalized to VC + IFN $\alpha /$ IL-7, which was considered to be a $100 \%$ maximum response for each individual donor, and the appropriate statistical test was performed (see figure legends).

\section{Results}

$\mathrm{CD4}^{+}$and $\mathrm{CD8}^{+} \mathrm{T}$ Cells from Healthy and $\mathrm{HIV}^{+}$ Donors Have Comparable Composition of Memory and Nonmemory Cells. As indicated in the Materials and Methods, $\mathrm{HIV}^{+}$donors for this study were chosen based on the following criteria: 1) not using medicinal or recreational cannabinoids; 2) $\mathrm{CD}^{+}{ }^{+}$T-cell counts (>500 counts/ $\mu \mathrm{l}$ ); 3) CD4/CD8 ratios $(>1)$; 4) not coinfected with hepatitis $(\mathrm{A}, \mathrm{B}$, or $\mathrm{C})$; and 5 ) currently receiving ART with nondetectable viral burdens. It is noteworthy that the number of $\mathrm{CD}^{+}$and $\mathrm{CD} 8^{+} \mathrm{T}$ cells provides only a partial view of the overall T-cell repertoire. $\mathrm{T}$ cells were also evaluated for CD45RO expression, which identifies memory T cells (Fig. 1A). No significant differences were observed in the composition of memory and nonmemory $\mathrm{CD}^{+}{ }^{+}$or $\mathrm{CD}^{+} \mathrm{T}$ cells between healthy and $\mathrm{HIV}^{+}$donors in this study (Fig. 1B).

IFN $\alpha$-Induced Phosphorylation of STAT1 in $\mathrm{CD4}^{+}$ and $\mathrm{CD8}^{+} \mathrm{T}$ Cells from Healthy Donors Was More Sensitive to THC-Mediated Suppression than T Cells from HIV $^{+}$Donors. The expression of $\mathrm{IFN} \alpha$ receptor (IFNAR) is known to be diminished in patients with chronic HIV infection (Hardy et al., 2009). Moreover, T cells from $\mathrm{HIV}^{+}$donors who have not undergone ART have an altered response to IFN $\alpha$ compared with the response to T cells from healthy donors (Hardy et al., 2009). Our results confirm these findings such that $\mathrm{CD} 4^{+} \mathrm{T}$ cells had diminished expression of IFNAR2 in our cohort of $\mathrm{HIV}^{+}$donors (Fig. 2A). By contrast, no differences were observed in the expression of IFNAR2 comparing $\mathrm{CD} 8^{+} \mathrm{T}$ cells from healthy and $\mathrm{HIV}^{+}$donors.

Presently, it is unknown how $\mathrm{T}$ cells from $\mathrm{HIV}^{+}$donors receiving ART respond to IFN $\alpha$ or THC. To address this, the phosphorylation of STAT1 in response to treatment with IFN $\alpha$ was quantified (Fig. 2B). CD4 ${ }^{+} \mathrm{T}$ cells from $\mathrm{HIV}^{+}$patients trended toward elevated background levels of pSTAT1 compared with $\mathrm{CD}^{+}{ }^{+} \mathrm{T}$ cells from healthy donors (Fig. 2, C-E), and this difference was statistically significant in the $\mathrm{CD}^{2} \mathrm{RO}^{-}$ (nonmemory) $\mathrm{CD} 4^{+} \mathrm{T}$ cells (Fig. 2E). Upon the addition of IFN $\alpha$, similar induction of pSTAT1 was observed in $\mathrm{CD} 4^{+}$ T cells from $\mathrm{HIV}^{+}$donors and healthy donors (Fig. 2, C-E). Conversely, $\mathrm{CD}^{+}$cells from $\mathrm{HIV}^{+}$donors had diminished levels of IFN $\alpha$-induced pSTAT1 compared with healthy donors (Fig. 2E). Furthermore, treatment with THC significantly suppressed IFN $\alpha$-induced pSTAT1 expression in $\mathrm{CD} 4^{+}$ and $\mathrm{CD}^{+} \mathrm{T}$ cells from both $\mathrm{HIV}^{+}$and healthy donors (Fig. 2, $\mathrm{C}-\mathrm{H}$ ), but $\mathrm{CD}_{45 \mathrm{RO}^{-}}$(nonmemory) $\mathrm{CD}^{+}{ }^{+} \mathrm{T}$ cells from $\mathrm{HIV}^{+}$ donors were less sensitive to THC-mediated suppression
A

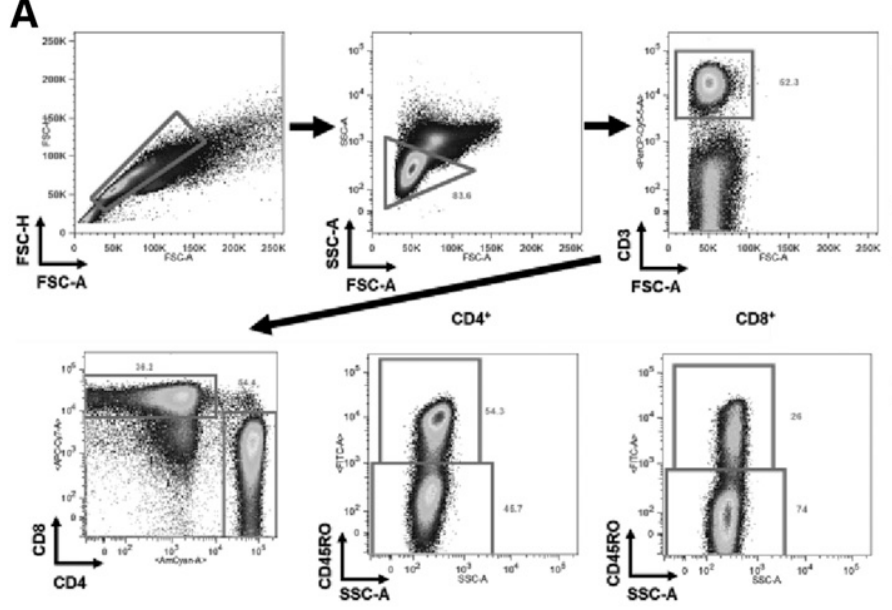

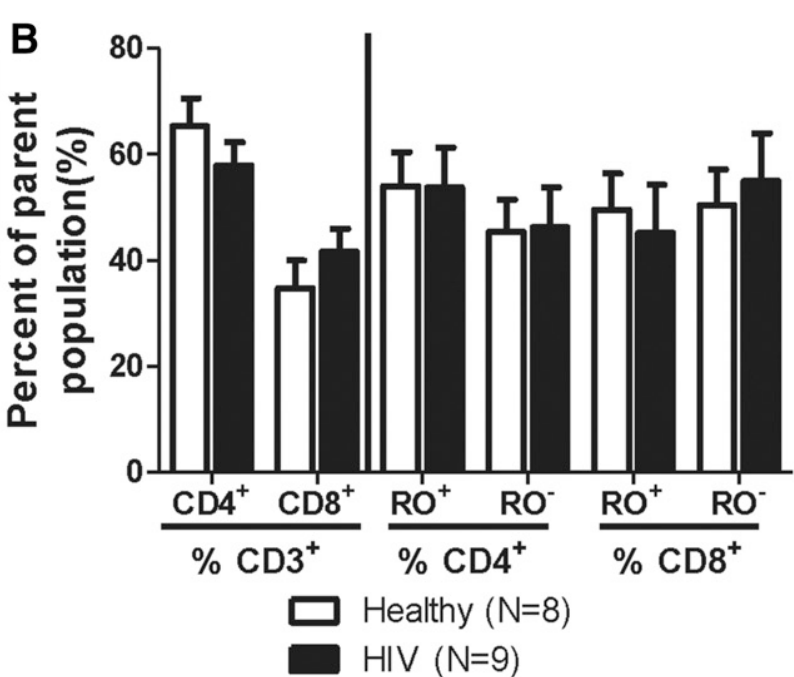

Fig. 1. Healthy and $\mathrm{HIV}^{+}$donors have comparable T-cell composition. (A) T cells were identified as CD3 ${ }^{+}$lymphocytes, and then classified as helper or cytotoxic T lymphocytes based upon the surface expression of CD4 and CD8, respectively. Memory T cells were identified as CD45RO ${ }^{+}$and nonmemory $\mathrm{T}$ cells were identified as $\mathrm{CD} 45 \mathrm{RO}^{-}$for both $\mathrm{CD}^{+}$and $\mathrm{CD} 8^{+} \mathrm{T}$ cells. (B) $\mathrm{HIV}^{+}$donors possessed $\mathrm{CD} 4^{+}$and $\mathrm{CD} 8^{+} \mathrm{T}$-cell numbers that were comparable to those of the healthy donors, and comparable memory $\left(\mathrm{CD} 45 \mathrm{RO}^{+}\right) /$nonmemory $\left(\mathrm{CD}^{2} 5 \mathrm{RO}^{-}\right)$cell composition. FSC-A, forward scatter area; $\mathrm{RO}^{-}$, $\mathrm{CD}^{2} 5 \mathrm{RO}^{-} ; \mathrm{RO}^{+}, \mathrm{CD} 4 \mathrm{RO}^{+}$; SSC-A, side scatter area. 
A

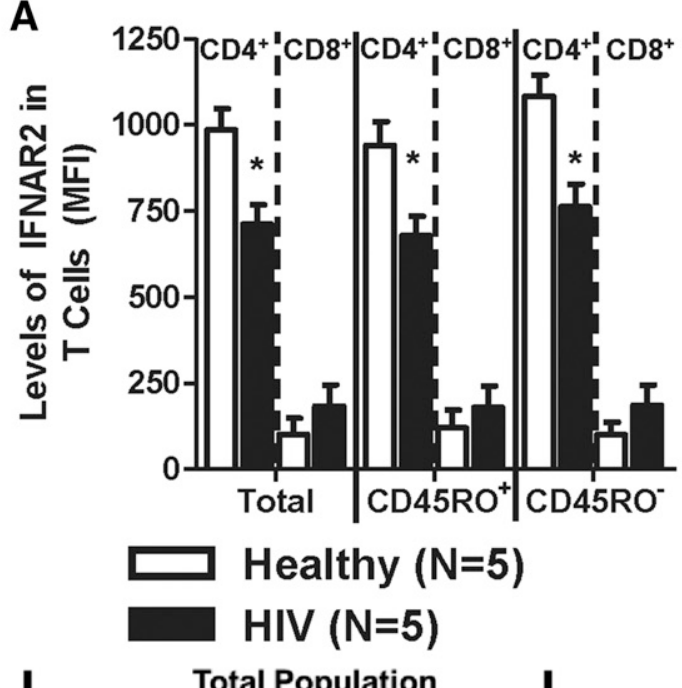

B
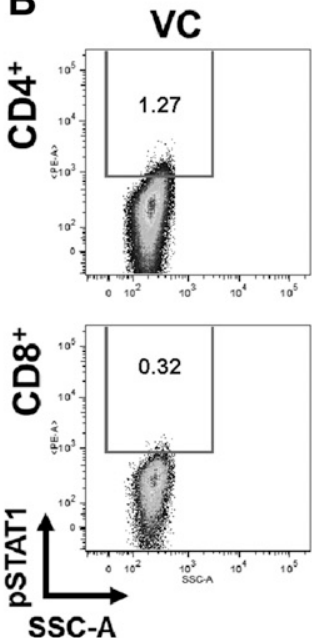
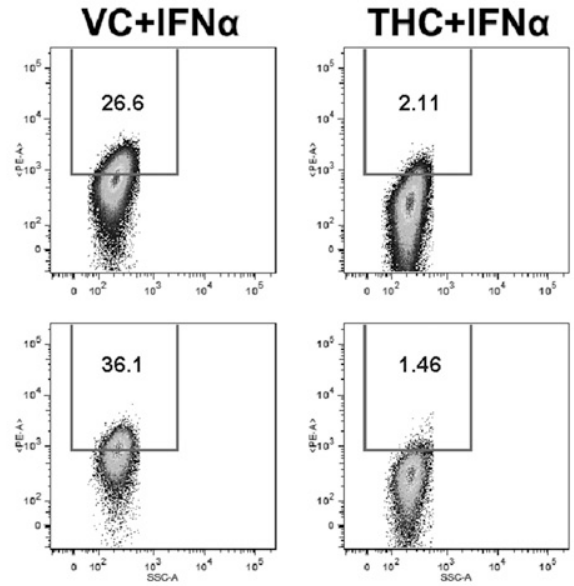

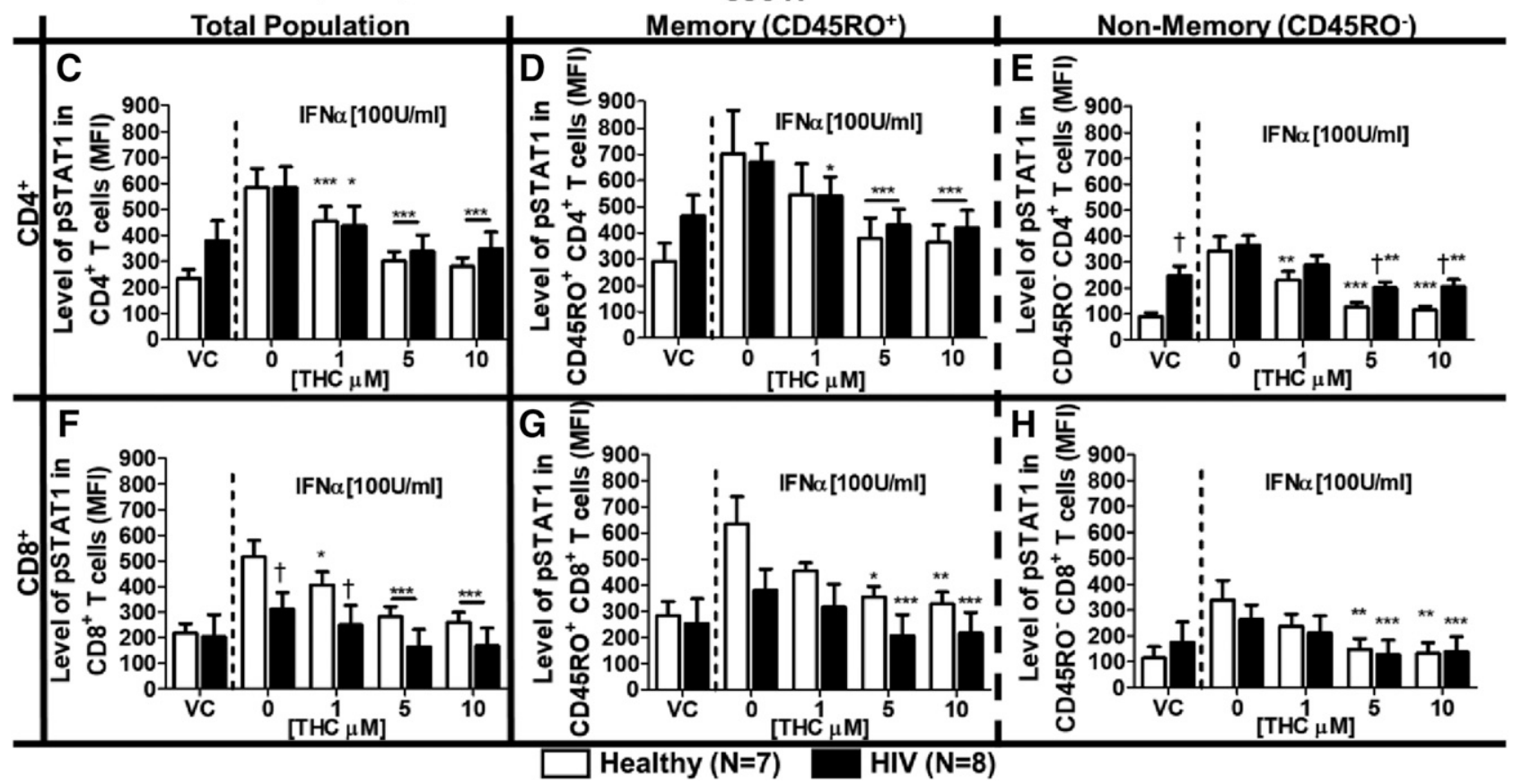

Fig. 2. T cells from healthy and $\mathrm{HIV}^{+}$donors exhibit different profiles of IFNAR2 expression and IFN $\alpha$-induced STAT1 phosphorylation, which is suppressed by THC. PBMCs from healthy and $\mathrm{HIV}^{+}$donors were isolated by Ficoll Paque density gradient centrifugation and used for the determination of either IFNAR2 surface expression or IFN $\alpha$-induced STAT1 phosphorylation (pSTAT1). (A) IFNAR2 expression was quantified by flow cytometry using the mean fluorescence intensity (MFI). For pSTAT1, PBMCs were treated with either vehicle $(0.03 \% \mathrm{EtOH})$ or THC $(1,5$, or $10 \mu \mathrm{M}$ ) in $0.03 \% \mathrm{EtOH}$ for 30 minutes before stimulation with $100 \mathrm{U} / \mathrm{ml} \mathrm{IFN} \alpha$ for 30 minutes. (B) Representative experiment of IFN $\alpha$-mediated pSTAT1 induction and THC $(10 \mu \mathrm{M})$-mediated suppression in T cells from a healthy donor. The effects of THC on IFN $\alpha$-pSTAT1 induction in: total (C), memory (D) and nonmemory (E) CD4 ${ }^{+} \mathrm{T}$ cells; and total (F), memory (G), and nonmemory (H) CD8 ${ }^{+}$T cells. For IFNAR2 expression, asterisks indicate statistically significant differences $(* P<0.05)$ of MFI in HIV compared with type-matched T cells from healthy donors. For pSTAT1, asterisks indicate statistically significant differences of the treatment with the HIV status-matched VC $(0$ THC $)(* P<0.05 ; * * P<0.01$; *** $P<0.001$ ). Daggers indicate statistically significant differences of treatment-matched groups between $\mathrm{T}$ cells from healthy and HIV ${ }^{+}$ donors $(\dagger P<0.05$ ) (two-way analysis of variance with Bonferroni multiple-comparisons post-test). SSC-A, side scatter area.

compared with $\mathrm{CD} 45 \mathrm{RO}^{-}$(nonmemory) $\mathrm{CD}^{+}{ }^{+} \mathrm{T}$ cells from healthy donors (Fig. 2E).

IFN $\alpha$ Upregulates IL-7R $\alpha$ Expression in T Cells from Healthy and HIV ${ }^{+}$Donors, and T Cells from Healthy Donors Were More Sensitive to THC-Mediated Suppression than T Cells from HIV $^{+}$Donors. Because the IL-7R $\alpha$ gene promoter region contains an IFN-sensitive responsible element (Mazzucchelli and Durum, 2007), studies were conducted in purified $\mathrm{T}$ cells from healthy donors to determine the effects of THC on IFN $\alpha$-induced IL-7R $\alpha$ mRNA expression. IFN $\alpha$ treatment induced mRNA expression of
IL-7R $\alpha$, which was significantly suppressed by THC (Fig. 3A). Interestingly, we found that the effects of IFN $\alpha$ on IFNAR2 expression were insensitive to THC treatment in T cells from healthy donors (Supplemental Fig. 1).

Studies were also performed to determine the direct effects of THC on IFN $\alpha$-induced IL-7R $\alpha$ protein expression (Fig. 3B). IFN $\alpha$ augmented the levels of cell surface IL-7R $\alpha$ expression on memory and nonmemory $\mathrm{CD}^{+}$and $\mathrm{CD}^{+} \mathrm{T}$ cells from healthy and $\mathrm{HIV}^{+}$donors (Fig. 3, C-H). In addition, THC produced differential effects between donor groups and T-cell populations. Specifically, $\mathrm{CD}_{4} 4 \mathrm{RO}^{-}$(nonmemory) $\mathrm{CD}^{+}$and 

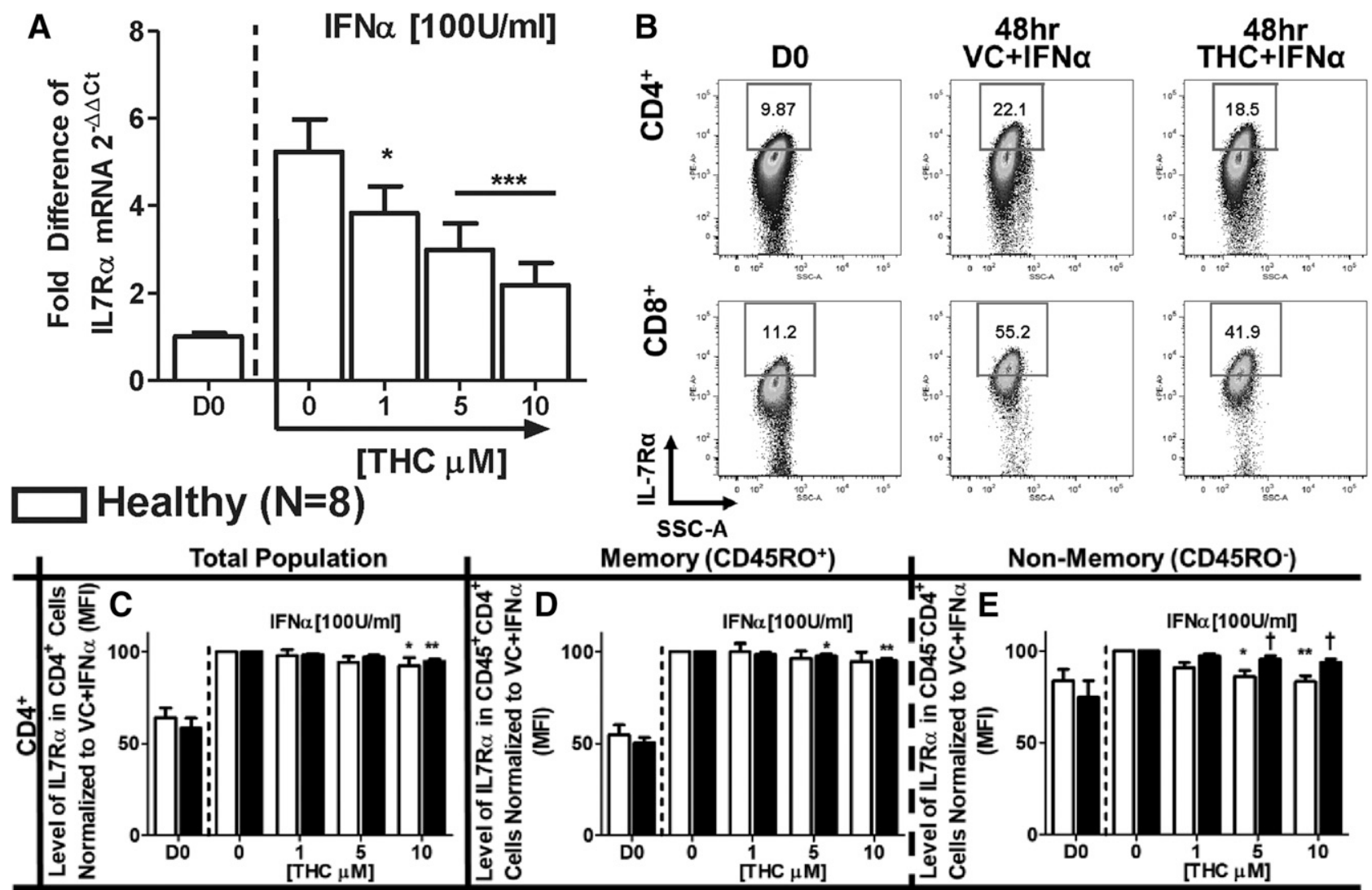

Non-Memory (CD45RO-)
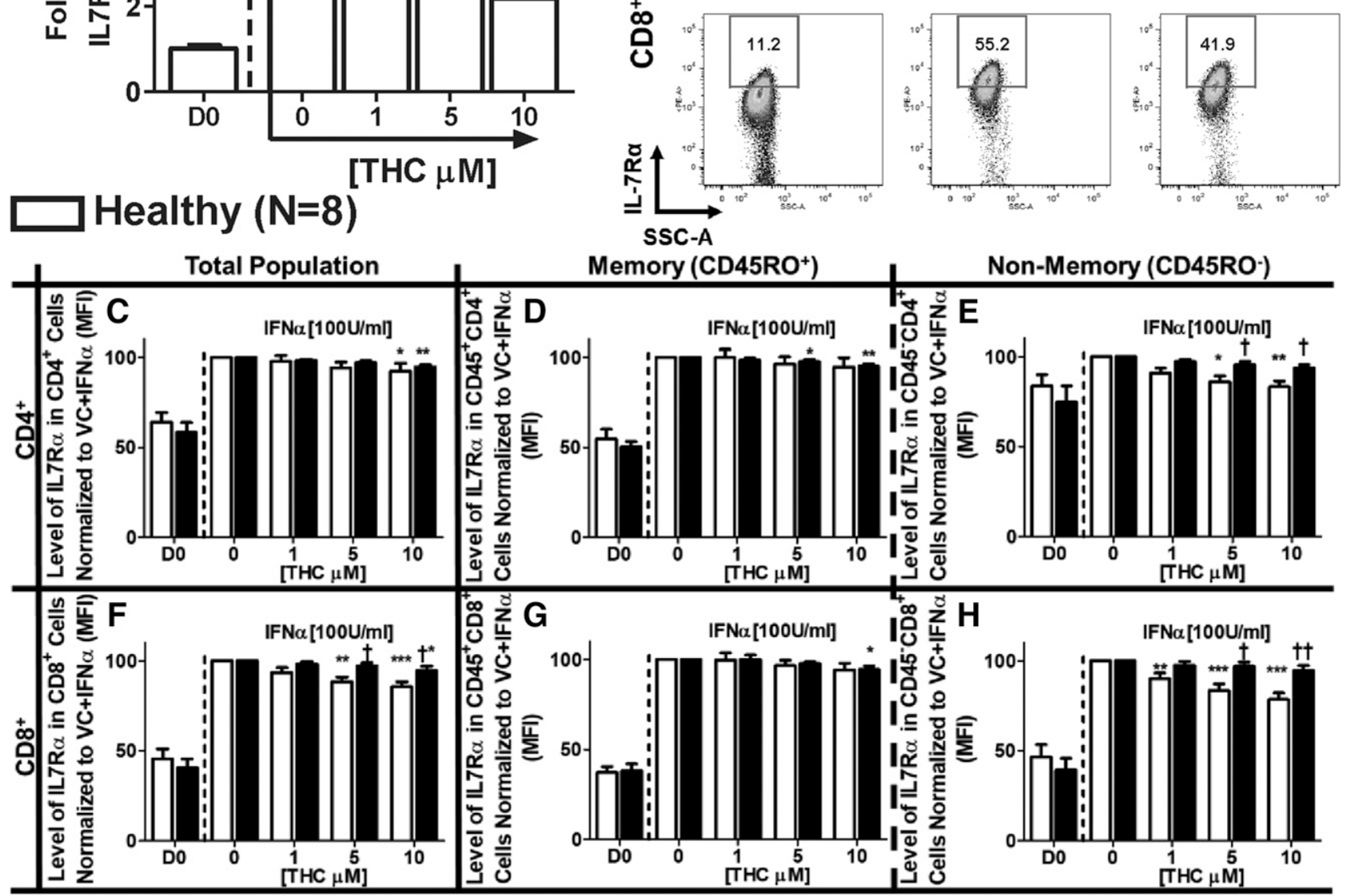

Healthy $(\mathrm{N}=7)$

HIV (N=6)

Fig. 3. THC suppresses IFN $\alpha$-induced expression of IL-7R $\alpha$ mRNA in T cells from healthy donors but differentially affects IFN $\alpha$-induced surface expression of IL-7R $\alpha$ in T cells from healthy vs. HIV ${ }^{+} \mathrm{T}$ donors. (A) To determine the effects of IFN $\alpha$ and THC on IL-7R $\alpha$ mRNA expression, T cells were purified from healthy donors, and treated with either vehicle $(0.03 \% \mathrm{EtOH})$ or various concentrations of THC $(1,5$, or $10 \mu \mathrm{M})$ for 30 minutes. After treatment, cells were stimulated with IFN $\alpha(100 \mathrm{U} / \mathrm{ml})$, incubated for 48 hours, and harvested for quantification of IL-7R $\alpha$ mRNA levels by real-time quantitative PCR. For the determination of IL-7R $\alpha$ surface expression, PBMCs from healthy and HIV $^{+}$donors were isolated through Ficoll Paque density gradient centrifugation and either immediately stained for CD3, CD4, CD8, CD45RO, and IL-7R $\alpha$ (D0) or treated with THC and IFN $\alpha$, as described above, and measured for IL-7R $\alpha$ expression after 48 hours. (B) Example of IFN $\alpha$-mediated IL-7R $\alpha$ expression and THC (10 $\mu \mathrm{M}$ )-mediated suppression in a healthy donor. The effects of THC on the expression level [mean fluorescence intensity (MFI)] of IL-7R $\alpha$ in T cells from healthy and HIV ${ }^{+}$ donors in total (C), memory (D), and nonmemory (E) CD4 ${ }^{+}$cells; and total (F), memory (G), and nonmemory (H) CD8 ${ }^{+}$cells. Asterisks indicate statistically significant differences of the treatment with the HIV status-matched VC ( 0 THC) $(* P \leq 0.05 ; * * P \leq 0.01 ; * * * P \leq 0.001)$. Daggers indicate statistically significant differences of treatment-matched groups between Healthy and $\mathrm{HIV}^{+} \mathrm{T}$ cells $(\dagger P \leq 0.05 ; \dagger+P \leq 0.01$ ) (two-way analysis of variance with Bonferroni multiple-comparisons post-test). D0, day 0; SSC-A, side scatter area.

$\mathrm{CD}^{+} \mathrm{T}$ cells from healthy donors exhibited greater sensitivity to THC-mediated suppression compared with matched $\mathrm{T}$ cells from $\mathrm{HIV}^{+}$donors and memory $\left(\mathrm{CD} 45 \mathrm{RO}^{+}\right)$cells (Fig. 3, E and $\mathrm{H}$ ).

IFNa Augments IL-7-Induced Phosphorylation of STAT5 in $\mathrm{CD4}^{+}$and $\mathrm{CD8}^{+} \mathrm{T}$ Cells from Healthy and $\mathrm{HIV}^{+}$Donors, and T Cells from Healthy Donors Were More Sensitive to THC-Mediated Suppression than T Cells from HIV ${ }^{+}$Donors. Cell surface receptor expression does not necessarily correlate with biologic activity described by the "spare receptor theory." By extension, the magnitude of IL-7R $\alpha$ expression is not necessarily indicative of receptor function, nor does it delineate differences between $\mathrm{T}$ cells from healthy and $\mathrm{HIV}^{+}$donors. Therefore, studies were performed to evaluate the effect of IFN $\alpha$ and THC on IL-7-induced signaling by quantifying the magnitude of STAT5 phosphorylation (Fig. 4A). These studies showed that $\mathrm{CD}^{+} \mathrm{T}$ cells from $\mathrm{HIV}^{+}$donors had diminished IL-7-induced pSTAT5 levels before IFN $\alpha$ stimulation compared with $\mathrm{CD}^{+} \mathrm{T}$ cells from healthy donors (Fig. 4B). Treatment with IFN $\alpha$ augmented IL-7-induced pSTAT5 in both $\mathrm{CD}^{+}$and $\mathrm{CD}^{+} \mathrm{T}$ cells from healthy and $\mathrm{HIV}^{+}$donors, which was suppressed by THC (Fig. 4, C-H). Moreover, both $\mathrm{CD}^{+}$and $\mathrm{CD}^{+}{ }^{+} \mathrm{T}$ cells from $\mathrm{HIV}^{+}$donors were 

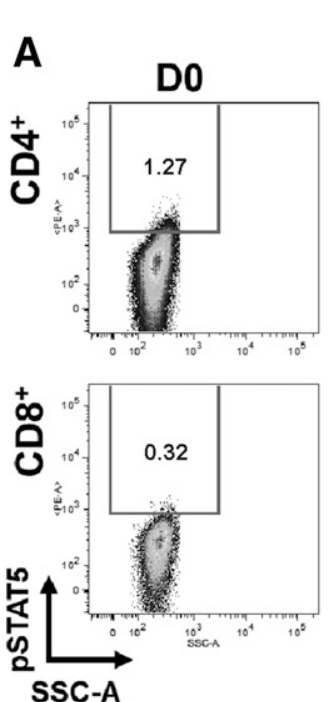

SSC-A
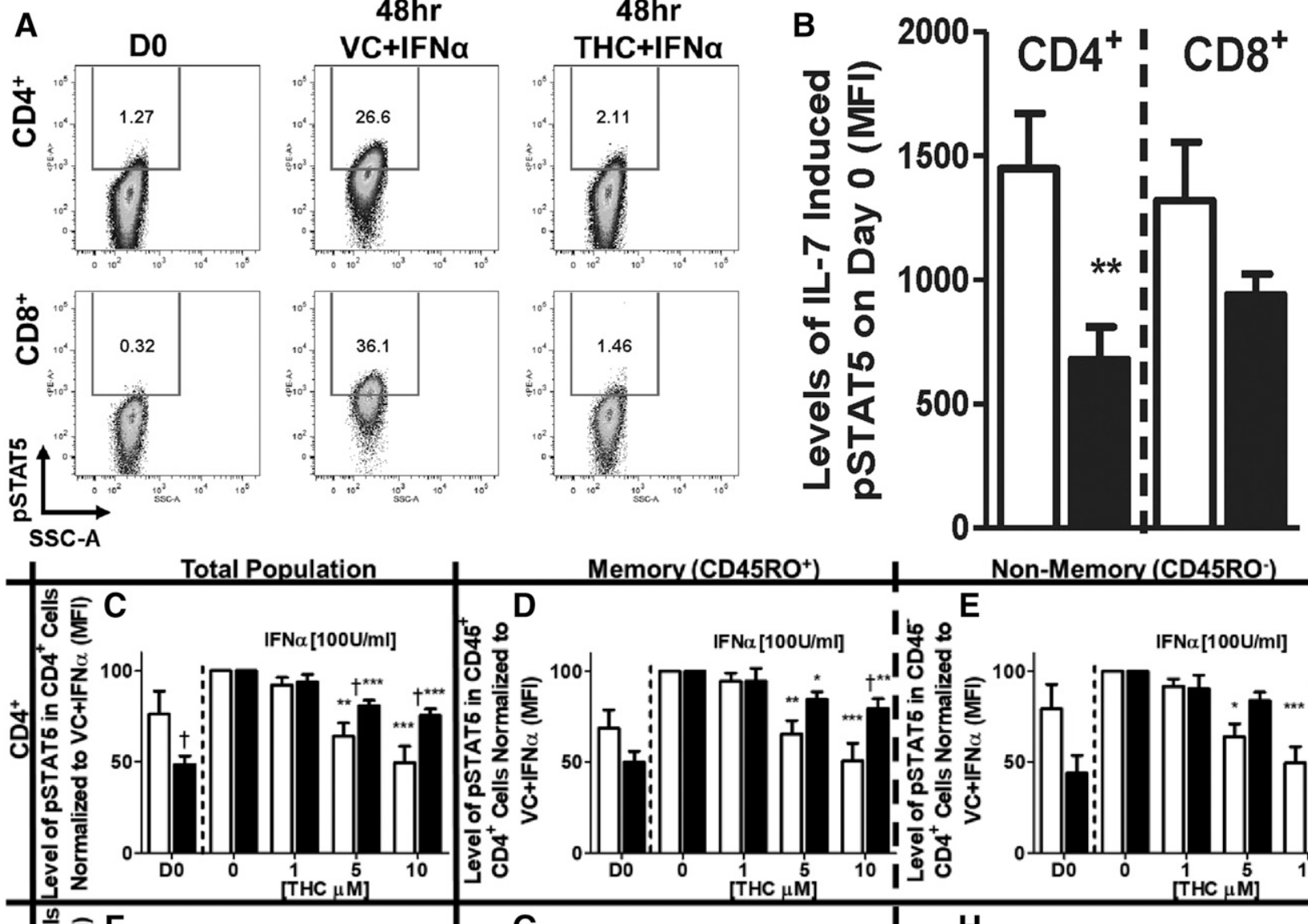

Memory (CD45RO+
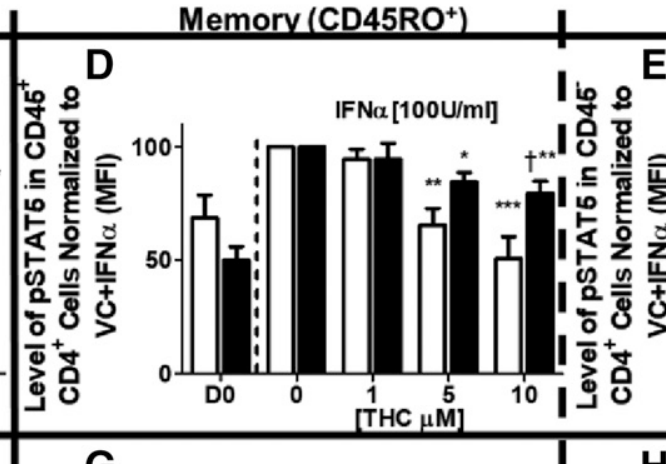

Non-Memory (CD45RO-)

E
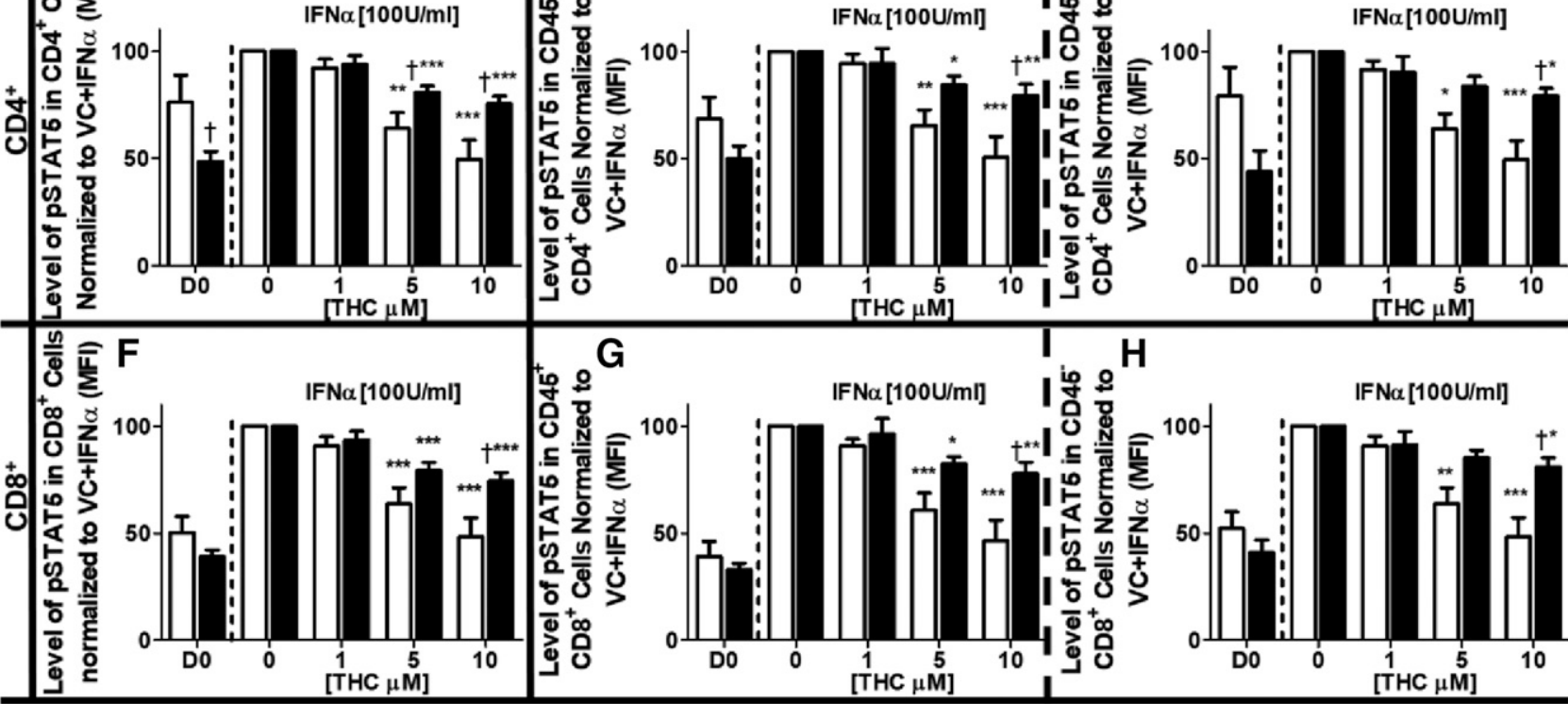

H

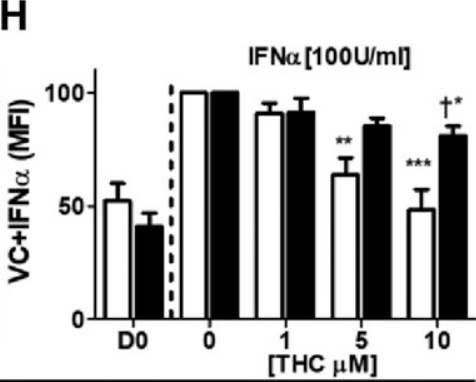

Healthy $(\mathrm{N}=7)$

HIV ( $\mathrm{N}=5)$

Fig. 4. THC suppresses IFN $\alpha$-mediated augmentation of IL-7-induced STAT5 phosphorylation. PBMCs from healthy and HIV ${ }^{+}$donors were isolated through Ficoll Paque density gradient centrifugation. Cells were either: 1) immediately used for the detection of IL-7-induced pSTAT5 (D0) by treating with IL-7 $(10 \mathrm{ng} / \mathrm{ml})$ for 15 minutes then rapidly fixed; or 2$)$ treated with either vehicle $(0.03 \% \mathrm{EtOH})$ or various concentrations of THC $(1,5$, or $10 \mu \mathrm{M})$ for 30 minutes, stimulated with IFN $\alpha$ (100 U/ml), incubated for 48, and then used for the detection of IL-7-induced pSTAT5, as described above. (A) Representative experiment of IL-7R $\alpha$-induced pSTAT5- and THC (10 $\mu \mathrm{M})$-mediated suppression in a healthy donor. (B) Levels [mean fluorescence intensity (MFI)] of pSTAT5 in T cells was determined by flow cytometry on day 0 . The effects of THC on the IL-7-induced pSTAT5 level after IFN $\alpha$ stimulation of T cells from healthy and $\mathrm{HIV}^{+}$donors in: total (C), memory (D), and nonmemory (E) $\mathrm{CD}^{+}$cells; and total (F), memory (G), and nonmemory $(\mathrm{H}) \mathrm{CD}^{+}$cells. Asterisks indicate statistically significant differences between treatments with the HIV status-matched VC $(0$ THC) $(* P \leq 0.05 ; * * P \leq$ 0.01 ; *** $P \leq 0.001)$. Daggers indicate statistically significant differences of treatment-matched groups between healthy and $\mathrm{HIV}^{+} \mathrm{T}$ cells $(\dagger P \leq 0.05)$ (two-way analysis of variance with Bonferroni multiple-comparisons post-test). D0, day 0; SSC-A, side scatter area.

less sensitive to THC-mediated suppression than cells from healthy donors, and the difference was significant when comparing both total and nonmemory $\left(\mathrm{CD} 45 \mathrm{RO}^{-}\right) \mathrm{CD}^{+}$(Fig. 4, $\mathrm{C}$ and $\mathrm{H}$ ) and $\mathrm{CD}^{+}$(Fig. 4, F and $\mathrm{H}$ ) T cells.

CD3/CD28/IFN $\alpha$-Induced Proliferation Was Augmented by IL-7 and Suppressed by THC in $\mathrm{CD8}^{+}$ T Cells Regardless of HIV Status, whereas $\mathrm{CD4}^{+}$ T Cells from $\mathrm{HIV}^{+}$Donors Were Less Sensitive to THC. The relationship between IFN $\alpha$ and IL-7 stimulation of $\mathrm{T}$ cells is poorly characterized (Catalfamo et al., 2011). To better understand how IFN $\alpha$ may affect the homeostatic role of IL-7, studies were performed to address whether IFN $\alpha$ induced augmentation of IL-7R expression and cognate signaling resulted in an enhanced T-cell proliferative response to IL-7. To mimic in vivo conditions using an in vitro system, $\mathrm{T}$ cells were stimulated using anti-CD3/CD28 antibodies and IFN $\alpha$ concurrently (i.e., the "three signal hypothesis") then stimulated with IL-7 at the peak time of IL-7R expression (48 hours). T-cell proliferation was quantified using a DI (Fig. $5 \mathrm{~A})$. Stimulation with IFN $\alpha$ had minimal augmentation of CD3/CD28-induced proliferation in isolation (Fig. 5, B and C). However, stimulation with IFN $\alpha$ before the addition of IL-7 

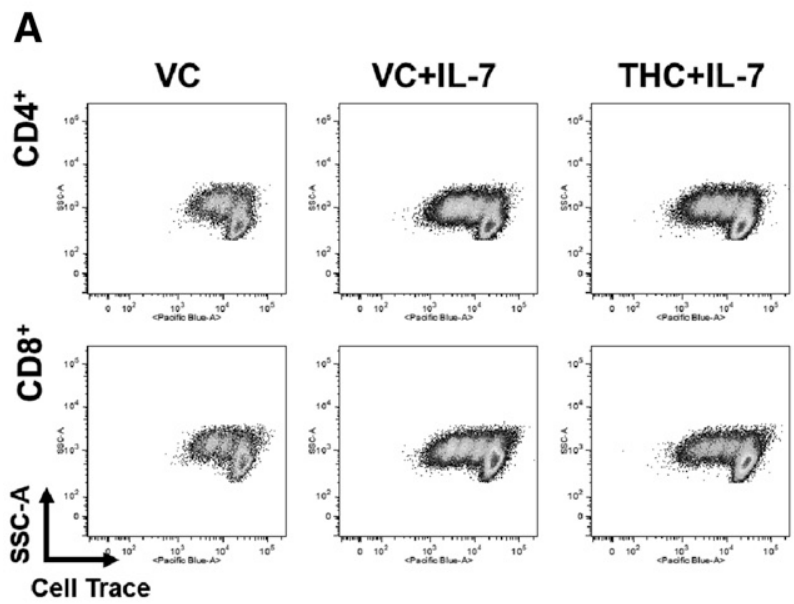
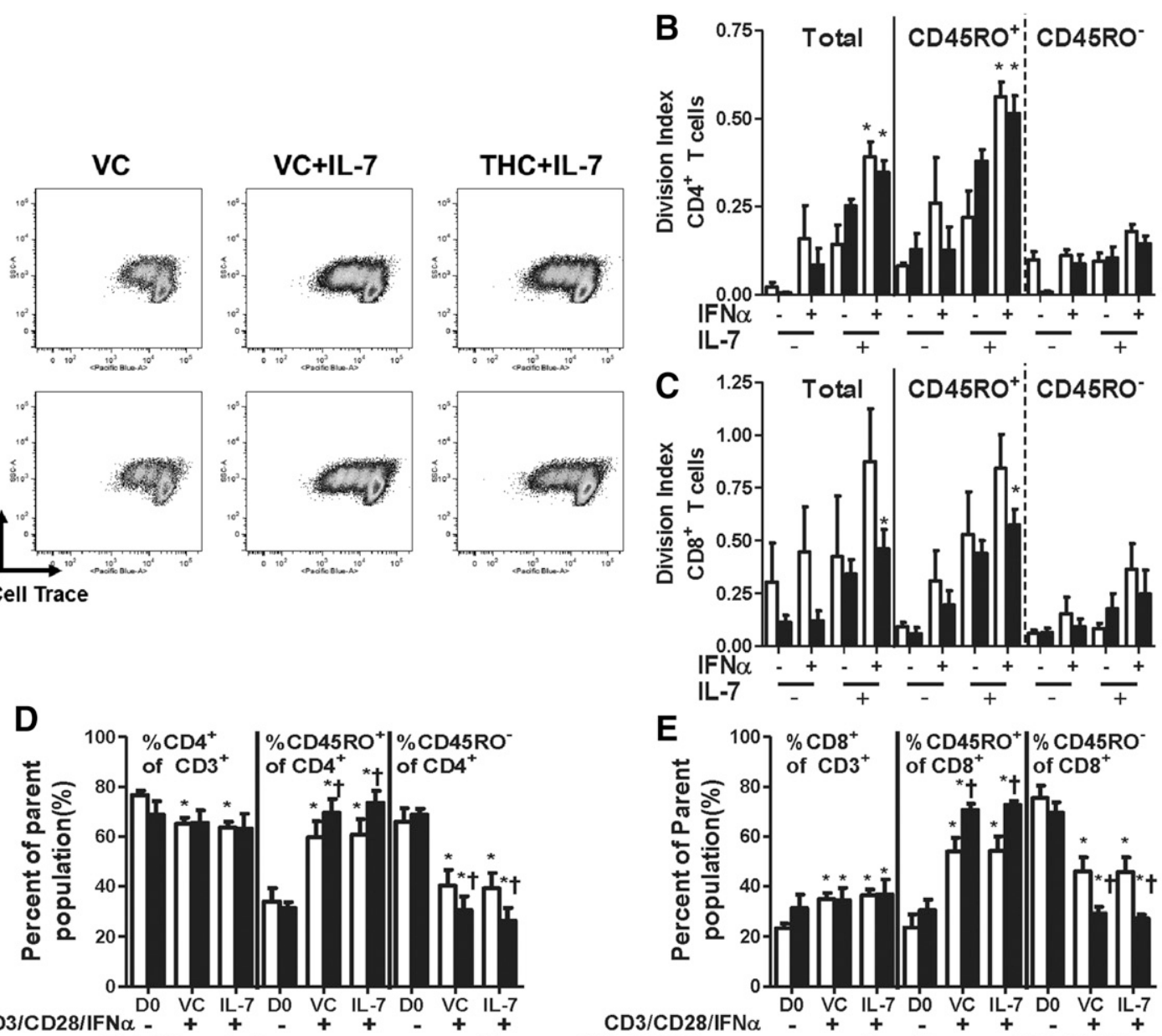

E
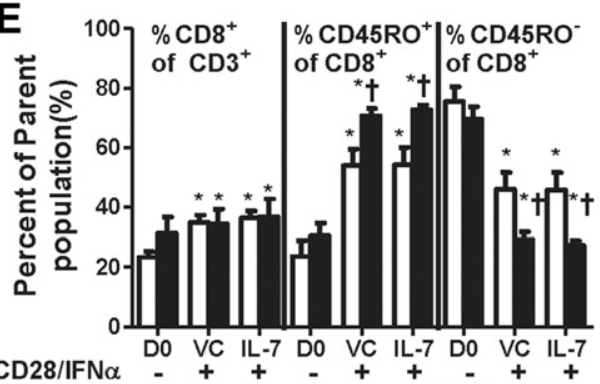

Non-Memory (CD45RO)

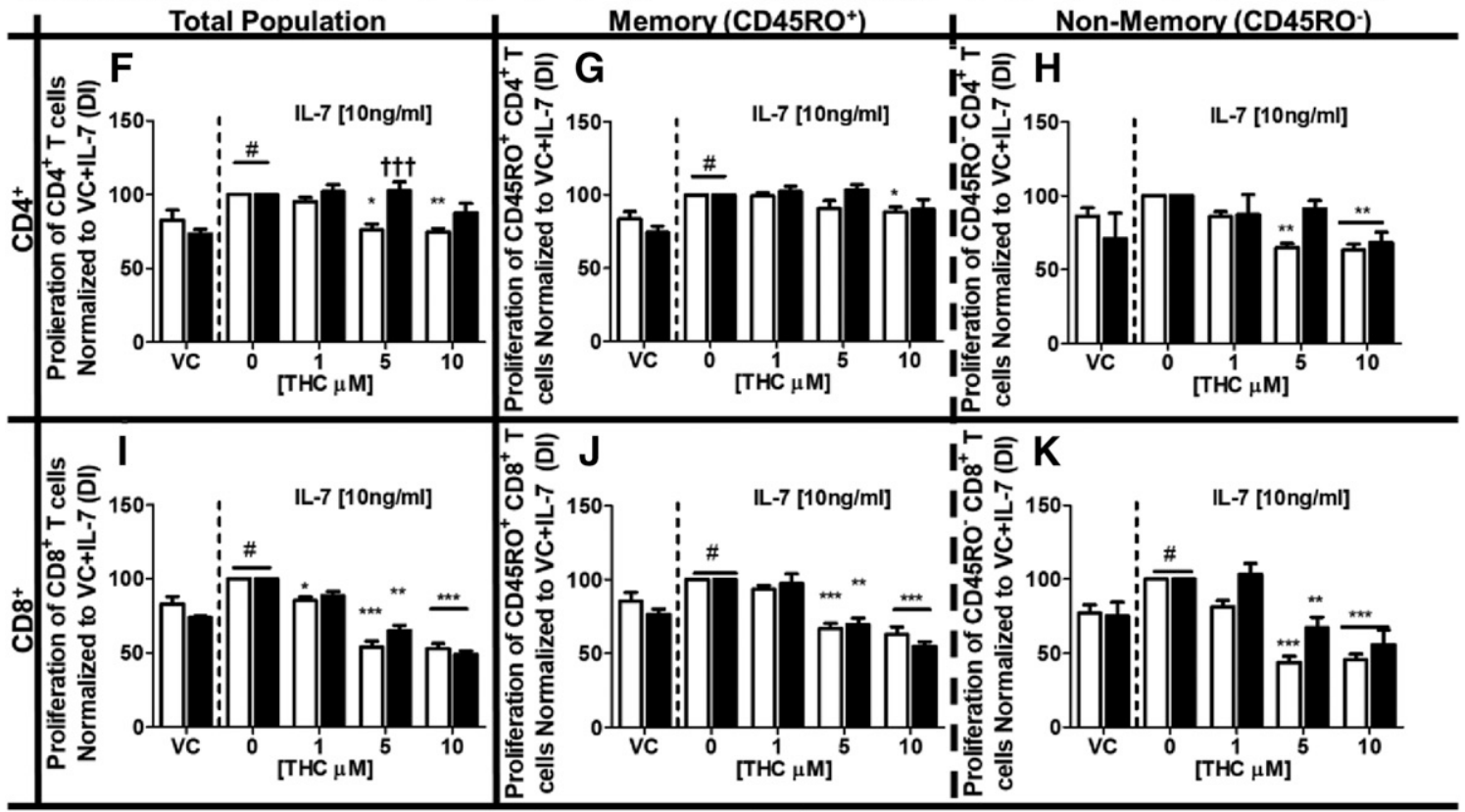

Healthy $(\mathrm{N}=8) \square \operatorname{HIV}(\mathrm{N}=4)$

Fig. 5. IL-7 augmented CD3/CD28/IFN $\alpha$-induced T-cell proliferation is suppressed by THC. PBMCs from healthy and HIV ${ }^{+}$donors were isolated through Ficoll Paque density gradient centrifugation. Cells were stained with violet CellTrace dye and then treated with either vehicle ( $0.03 \%$ EtOH) or various concentrations of THC $(1,5$, or $10 \mu \mathrm{M})$ for 30 minutes. After treatment, cells were stimulated with IFN $\alpha$ (100 U/ml) and anti-CD3 and anti-CD28 antibodies $\left(2.5 \mu \mathrm{g} / \mathrm{ml}\right.$ each) for 48 hours, treated with IL-7 $(10 \mathrm{ng} / \mathrm{ml})$ or vehicle (endotoxin-free $\mathrm{H}_{2} \mathrm{O}$ ), and incubated for another 48 hours before harvesting. T-cell proliferation is represented as the DI, as determined by the FlowJo proliferation tool. (A) Representative experiment of IL-7-mediated augmentation of T-cell proliferation in CD3/CD28/IFN $\alpha$-stimulated T cells and THC (10 $\mu \mathrm{M})$-mediated suppression in a healthy donor. The effects of treatment with IFN $\alpha$ and IL-7 on anti-CD3/CD28-mediated T-cell proliferation in CD4 ${ }^{+}(\mathrm{B})$ and $\mathrm{CD}^{+}(\mathrm{C}) \mathrm{T}$ cells from healthy and HIV ${ }^{+}$donors. The effect of IL-7 stimulation on total CD3 ${ }^{+}$T-cell composition and between memory $\left(\mathrm{CD} 45 \mathrm{RO}^{+}\right)$and nonmemory $\left(\mathrm{CD} 45 \mathrm{RO}^{-}\right)$cells in $\mathrm{CD}^{+}(\mathrm{D})$ and $\mathrm{CD} 8^{+}$ 
resulted in a significantly stronger proliferative response compared with anti-CD3/CD28 stimulation alone in CD4 ${ }^{+}$ $\mathrm{T}$ cells from both healthy and $\mathrm{HIV}^{+}$donors (Fig. 5B). This phenomenon was also observed in $\mathrm{CD}^{+} \mathrm{T}$ cells from $\mathrm{HIV}^{+}$ donors (Fig. 5C). Stimulation with CD3/CD28/IFN $\alpha$ also increased the proportion of $\mathrm{CD} 45 \mathrm{RO}^{+}$(memory) cells in $\mathrm{CD}^{+}$and $\mathrm{CD}^{+} \mathrm{T}$ cells and was more pronounced in $\mathrm{HIV}^{+}$ donors, but was not significantly affected by treatment with IL-7 (Fig. 5, D and E). In the presence of THC, CD4 ${ }^{+}$and CD8 ${ }^{+}$ $\mathrm{T}$ cells from healthy donors showed a diminished proliferative response to control-treated cells (Fig. 5, F-K). Interestingly, THC-mediated suppression of the proliferative response was diminished in $\mathrm{CD}^{+}{ }^{+} \mathrm{T}$ cells from $\mathrm{HIV}^{+}$donors compared with healthy donors (Fig. 5, F-H). By contrast, $\mathrm{CD}^{+} \mathrm{T}$ cells from $\mathrm{HIV}^{+}$donors showed suppression in the presence of THC that was comparable to the degree of THC-mediated suppression in $\mathrm{CD}^{+} \mathrm{T}$ cells from healthy donors (Fig. 5, I-K).

\section{Discussion}

Presented here is the first report of differential THCmediated suppression in response to IFN $\alpha$ by $\mathrm{T}$ cells from healthy and HIV-infected donors. Our goals were to investigate whether HIV infection affects the role of IFN $\alpha$ in maintaining peripheral T-cell populations and to determine whether cannabinoids can influence these processes. To address these goals, donors included in this study had no detectable HIV viral load, were not coinfected with any screened pathogen, did not use cannabinoids, and had comparable $\mathrm{CD}^{+}{ }^{+}$as well as $\mathrm{CD} 8^{+}$T-cell counts.

Although the similarity of $\mathrm{CD}^{+}$and $\mathrm{CD}^{+}$T-cell composition was critical for making comparisons between healthy and $\mathrm{HIV}^{+}$donors, HIV infection is known to alter the number and function of certain immune cells (Donaghy et al., 2001; Chehimi et al., 2002; Gulzar and Copeland, 2004; Benlahrech and Patterson, 2011; Catalfamo et al., 2011; Février et al., 2011; Rizzo et al., 2017). Therefore, we investigated the responsiveness of T cells to IFN $\alpha$, which is crucial to maintaining T-cell homeostasis and is a critical mediator of antiviral responses. We found that IFN $\alpha$-induced phosphorylation of STAT1, one of the most proximal biologic events in response to ligation of the IFNAR2, differed between healthy and $\mathrm{HIV}^{+} \mathrm{CD}^{+}$ $\mathrm{T}$ cells. Specifically, $\mathrm{CD}^{+} \mathrm{T}$ cells from $\mathrm{HIV}^{+}$donors were less responsive to IFN $\alpha$, as evidenced by reduced pSTAT1. Moreover, this difference was not observed in $\mathrm{CD}^{+}{ }^{+} \mathrm{T}$ cells even though HIV-derived $\mathrm{CD}^{+} \mathrm{T}$ cells possessed lower IFNAR2 expression than those from healthy donors. CD ${ }^{+}$ $\mathrm{T}$ cells from $\mathrm{HIV}^{+}$donors also had lower pSTAT1 induction compared with $\mathrm{CD}^{+}$cells from healthy donors despite having comparable IFNAR2 expression. These observations agree with previous findings (Rodriguez et al., 2006) that demonstrated that $\mathrm{CD}^{+}$and $\mathrm{CD}^{+} \mathrm{T}$ cells from $\mathrm{HIV}^{+}$ patients had differential responses to IFN $\alpha$-mediated stimulation. These data also indicate that $\mathrm{CD}^{+} \mathrm{T}$ cells in $\mathrm{HIV}^{+}$ donors have a diminished response to IFN $\alpha$-mediated activation while strengthening the link between the role of IFN $\alpha$ in directing $\mathrm{CD}^{+}{ }^{+} \mathrm{T}$ cells in viral infection (Brinkmann et al., 1993).

The differential effects of IFN $\alpha$ in stimulating T-cell subtypes is significant in HIV infection because IFN $\alpha$ plays a key role in maintaining activated T-cell populations (Marrack et al., 1999; Kolumam et al., 2005; Huber and Farrar, 2011) and potentially synergizes with IL-7 to stimulate $\mathrm{HIV}^{+}$donor T cells (Catalfamo et al., 2011). We show here that IFN $\alpha$ drives IL-7R expression and potentiates IL-7 signaling, as evidenced by augmented IL-7-induced pSTAT5, in cells treated with IFN $\alpha$. We also show that IL-7 drove robust proliferation of T cells treated with IFN $\alpha$. These results partially agree with previous findings (Cha et al., 2014) and strengthen the link among IFN $\alpha$, pDC number, and CD4 ${ }^{+}$ T-cell number in $\mathrm{HIV}^{+}$patients (Lapenta et al., 1999; Rissoan et al., 1999; Donaghy et al., 2001; Rodriguez et al., 2006). Specifically, circulating $\mathrm{pDCs}$ secrete $\mathrm{IFN} \alpha$, which may play a role in sensitizing $\mathrm{T}$ cells in their response to IL-7.

$\mathrm{HIV}^{+}$patients routinely use medicinal cannabinoids (Abrams, 2000; Prentiss et al., 2004; Haney et al., 2007; Ellis et al., 2009). Cannabis use reduces the efficacy of IFN $\alpha$ as a therapeutic agent (Gross et al., 1991). Among healthy donors, the observed suppressive effect of THC on T-cell activation by IFN $\alpha$ is mediated, at least in part, by decreased STAT1 phosphorylation. This observation agrees with previous work on IFN $\beta$, which also binds IFNAR (Kozela et al., 2010). Likewise, THC also suppresses the induction of IL-7R $\alpha$ mRNA and protein expression, which putatively is mediated through the loss of both homo- and hetero-STAT-dimer formation and subsequent gene transcription. Additionally, THC significantly suppresses the effects of IL-7 on proliferation, likely through the suppression of IL-7-induced STAT5 phosphorylation. Interestingly, THC had no effect on the IFN $\alpha$-induced expression of IFNAR2, indicating that THC has a specific effect on the IFN $\alpha$-IL-7 axis.

The most surprising finding of these studies was the reduced sensitivity of $\mathrm{T}$ cells in patients with $\mathrm{HIV}$ to $\mathrm{THC}$ mediated suppression. Although the initial suppression of IFN $\alpha$-induced pSTAT1 showed similar trends in both healthy and HIV-infected donors, endpoints temporally distal to STAT1 phosphorylation demonstrated reduced sensitivity to THC-mediated suppression in $\mathrm{T}$ cells from HIV-infected donors. This trend was most pronounced in $\mathrm{CD}^{+}{ }^{+} \mathrm{T}$ cells from HIV donors, especially with respect to proliferation. This finding, although unexpected, agrees with those of previous studies showing that $\mathrm{CD} 4^{+} \mathrm{T}$-cell number was not affected in $\mathrm{HIV}^{+}$patients using medicinal marijuana (Abrams et al., 2003). Conversely, $\mathrm{CD}^{+} \mathrm{T}^{\mathrm{T}}$ cells from $\mathrm{HIV}^{+}$patients showed marked suppression of proliferation by THC despite being less sensitive to THC-mediated impairment of other endpoints.

The limitations of these studies underlie possible reasons for the observed differences. First, the composition of the

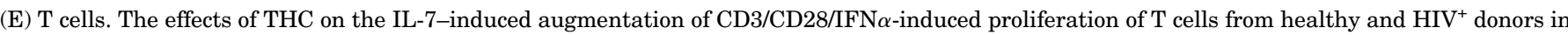

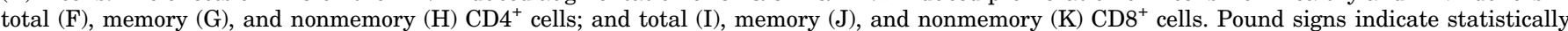

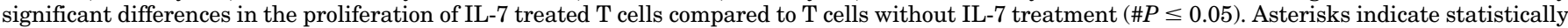

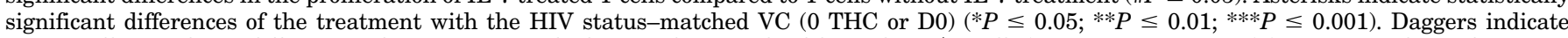

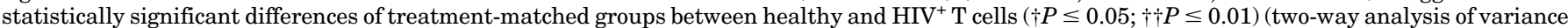
with Bonferroni multiple-comparisons post-test). D0, day 0; SSC-A, side scatter area.
} 
memory and nonmemory cells could produce some of the differences in IFN $\alpha$-mediated activation and sensitivity to THC. Memory T cells can be divided into central and effector cells, and nonmemory cells can be divided into naive and effector cells by using surface expression of CD62L (Ammirati et al., 2012). Furthermore, we did not distinguish the $\mathrm{T}$ regulatory (Treg) $\mathrm{CD}^{+}{ }^{+} \mathrm{T}$ cells from non-Treg-CD4 ${ }^{+}$ $\mathrm{T}$ cells. It is noteworthy that IFN $\alpha$ can suppress Treg function (Becker et al., 2013). Last, proliferation was induced by simulating a T-cell receptor-like response using antibodies directed against CD3 and CD28, which differs from antigenspecific stimulation (Lo et al., 2013).

Most significantly, our studies were designed to limit the number of confounding factors by using only male $\mathrm{HIV}^{+}$ patients with the following: 1) $\mathrm{CD} 4{ }^{+} \mathrm{T}$-cell counts comparable to those of healthy donors; 2) CD4/CD8 T-cell ratios within the normal range $(>1)$; 3) no coinfection with any strain of hepatitis; and 4) no medicinal or current recreational cannabinoid use. Although these parameters enabled a direct comparison with healthy donors, the profiles for T-cell activation presented in this article may vary significantly from other $\mathrm{HIV}^{+}$patient populations. Specifically, our data do not address 1) the effects of HIV infection in female $\mathrm{HIV}^{+}$patients, who have different immunologic responses to HIV infection compared with men (Berghöfer et al., 2006; Meier et al., 2009; Addo and Altfeld, 2014); 2) patients with HIV treated successfully with ART without restoration of $\mathrm{CD}^{+}{ }^{+} \mathrm{T}$-cell counts, which have elevated $\mathrm{CD}^{+}$T-cell activity and higher HIV-related mortality (Kelley et al., 2009; Serrano-Villar et al., 2014); 3) patients coinfected with a virus, since infections with hepatitis $\mathrm{C}$ virus can alter IFN responses and T-cell activation (Lincoln et al., 2003; Dolganiuc et al., 2006); 4) patients with HIV experiencing early versus established T-cell exhaustion, since the response to IL-7 likely changes as IL-7R expression is lost and as T-cell exhaustion progresses (Yi et al., 2010); and 5) patients using medicinal cannabinoids, since chronic THC exposure can lead to tolerance through various pharmacodynamic mechanisms (González et al., 2005), but it is unknown whether chronic cannabis use can lead to THC tolerance in leukocytes. Finally, these studies were designed to address the effects of THC treatment on early signaling events by IFN $\alpha, \mathrm{CD} 3 / \mathrm{CD} 28$, and IL-7-mediated stimulation by single-dose pretreatment with THC, and do not address the effects of repeat treatment of THC or of THC treatment on established effector cell functions. Further studies will be required to characterize the effects of THC in these various patient and cell populations to understand the consequences of cannabinoid use by $\mathrm{HIV}^{+}$ patients.

The findings presented in this article are the first to show a direct link between IFN $\alpha$ - and IL-7-mediated augmentation of CD3/CD28-induced T-cell proliferation. This work is also the first to show differences in the sensitivity to THC-mediated modulation of T-cell stimulation from healthy and HIV-infected donors. The implications of this work are complex and multifaceted. Specifically, IFN $\alpha$ secretion by $\mathrm{pDCs}$ from $\mathrm{HIV}^{+}$donors is acutely sensitive to THC-mediated suppression (Henriquez et al., 2017), and elevated activation of pDCs in women with HIV is linked to faster T-cell depletion (Berghöfer et al., 2006), which is associated with more severe neurocognitive deficiency (Burlacu et al., 2018). Additionally, peripheral immune activation of $\mathrm{CD}^{+}$T cells (Kessing et al., 2017) and monocytes is tied to the development of HIV-associated neural inflammation, which could explain why cannabis users have reduced inflammatory monocyte numbers (Rizzo et al., 2017). Collectively, our findings imply that the use of cannabinoids by $\mathrm{HIV}^{+}$ patients undergoing ART may be beneficial within the context of suppressing the activation of cell association with neural inflammation while maintaining $\mathrm{CD}^{+}{ }^{+} \mathrm{T}$ cells largely unaffected.

\section{Acknowledgments}

We thank Linda Dale, for coordinating blood collection from $\mathrm{HIV}^{+}$ donors; Yulia Pepelyayeva and Patrick O'Connell, for assisting with the isolation of PBMCs from healthy and $\mathrm{HIV}^{+}$donors; Jiajun Zhou, for formatting figures in preparation for article submission; and Kimberly Hambleton for assistance in the submission of this article.

\section{Authorship Contributions}

Participated in research design: Henriquez, Rizzo, Crawford, Gulick, and Kaminski.

Conducted experiments: Henriquez and Rizzo.

Performed data analysis: Henriquez.

Wrote or contributed to the writing of the manuscript: Henriquez and Kaminski.

\section{References}

Abrams DI (2000) Potential interventions for HIV/AIDS wasting: an overview. $J$ Acquir Immune Defic Syndr 25 (Suppl 1):S74-S80.

Abrams DI, Hilton JF, Leiser RJ, Shade SB, Elbeik TA, Aweeka FT, Benowitz NL Bredt BM, Kosel B, Aberg JA, et al. (2003) Short-term effects of cannabinoids in patients with HIV-1 infection: a randomized, placebo-controlled clinical trial. Ann Intern Med 139:258-266.

Addo MM and Altfeld M (2014) Sex-based differences in HIV type 1 pathogenesis. $J$ Infect Dis 209 (Suppl 3):S86-S92.

Ammirati E, Cianflone D, Vecchio V, Banfi M, Vermi AC, De Metrio M, Grigore L, Pellegatta F, Pirillo A, Garlaschelli K, et al. (2012) Effector memory T cells are associated with atherosclerosis in humans and animal models. $J$ Am Heart Assoc 1: $27-41$.

Autran B, Carcelain G, Li TS, Blanc C, Mathez D, Tubiana R, Katlama C, Debré P, and Leibowitch J (1997) Positive effects of combined antiretroviral therapy on CD4 $+\mathrm{T}$ cell homeostasis and function in advanced HIV disease. Science 277: 112-116.

Bazdar DA and Sieg SF (2007) Interleukin-7 enhances proliferation responses to $\mathrm{T}$-cell receptor stimulation in naïve $\mathrm{CD} 4+\mathrm{T}$ cells from human immunodeficiency virus-infected persons. J Virol 81:12670-12674.

Becker C, Bopp T, and Steinbrink K (2013) Interferon $\alpha$ interferes with immunological tolerance. OncoImmunology 2:e27528.

Benlahrech A and Patterson S (2011) HIV-1 infection and induction of interferon alpha in plasmacytoid dendritic cells. Curr Opin HIV AIDS 6:373-378.

Berghöfer B, Frommer T, Haley G, Fink L, Bein G, and Hackstein H (2006) TLR7 ligands induce higher IFN- $\alpha$ production in females. J Immunol 177:2088-2096.

Brinkmann V, Geiger T, Alkan S, and Heusser CH (1993) Interferon alpha increase the frequency of interferon gamma-producing human CD4+ T cells. J Exp Med 178:1655-1663.

Burlacu R, Umlauf A, Luca A, Gianella S, Radoi R, Ruta SM, Marcotte TD, Ene L, and Achim CL (2018) Sex-based differences in neurocognitive functioning in HIV infected young adults. AIDS 32:217-225.

Catalfamo M, Wilhelm C, Tcheung L, Proschan M, Friesen T, Park J-H, Adelsberger J, Baseler M, Maldarelli F, Davey R, et al. (2011) CD4 and CD8 T cell immune activation during chronic HIV infection: roles of homeostasis, HIV, type I IFN, and IL-7. J Immunol 186:2106-2116.

Cha L, de Jong E, French MA, and Fernandez S (2014) IFN- $\alpha$ exerts opposing effects on activation-induced and IL-7-induced proliferation of $\mathrm{T}$ cells that may impair homeostatic maintenance of CD4 $+\mathrm{T}$ cell numbers in treated HIV infection. $J$ Immunol 193:2178-2186.

Chehimi J, Campbell DE, Azzoni L, Bacheller D, Papasavvas E, Jerandi G, Mounzer K, Kostman J, Trinchieri G, and Montaner LJ (2002) Persistent decreases in blood plasmacytoid dendritic cell number and function despite effective highly active antiretroviral therapy and increased blood myeloid dendritic cells in HIV-infected individuals. $J$ Immunol 168:4796-4801.

Colonna M, Trinchieri G, and Liu Y-J (2004) Plasmacytoid dendritic cells in immunity. Nat Immunol 5:1219-1226.

Dolganiuc A, Chang S, Kodys K, Mandrekar P, Bakis G, Cormier M, and Szabo G (2006) Hepatitis C virus (HCV) core protein-induced, monocyte-mediated mechanisms of reduced IFN- $\alpha$ and plasmacytoid dendritic cell loss in chronic HCV infection. J Immunol 177:6758-6768.

Donaghy H, Pozniak A, Gazzard B, Qazi N, Gilmour J, Gotch F, and Patterson S (2001) Loss of blood CD11c(+) myeloid and CD11c(-) plasmacytoid dendritic cells in patients with HIV-1 infection correlates with HIV-1 RNA virus load. Blood 98: $2574-2576$ 
Dragic T, Litwin V, Allaway GP, Martin SR, Huang Y, Nagashima KA, Cayanan C, Maddon PJ, Koup RA, Moore JP, et al. (1996) HIV-1 entry into CD4+ cells is mediated by the chemokine receptor CC-CKR-5. Nature 381:667-673.

Eisenstein TK and Meissler JJ (2015) Effects of cannabinoids on T-cell function and resistance to infection. J Neuroimmune Pharmacol 10:204-216.

Ellis RJ, Toperoff W, Vaida F, van den Brande G, Gonzales J, Gouaux B, Bentley H, and Atkinson JH (2009) Smoked medicinal cannabis for neuropathic pain in HIV: a randomized, crossover clinical trial. Neuropsychopharmacology 34:672-680.

Février M, Dorgham K, and Rebollo A (2011) CD4+ T cell depletion in human immunodeficiency virus (HIV) infection: role of apoptosis. Viruses 3:586-612.

García-Sastre A and Biron CA (2006) Type 1 interferons and the virus-host relationship: a lesson in détente. Science 312:879-882.

González S, Cebeira M, and Fernández-Ruiz J (2005) Cannabinoid tolerance and dependence: a review of studies in laboratory animals. Pharmacol Biochem Behav 81:300-318.

Gross G, Roussaki A, Ikenberg H, and Drees N (1991) Genital warts do not respond to systemic recombinant interferon alfa-2a treatment during cannabis consumption. Dermatologica 183:203-207.

Gulzar N and Copeland KF (2004) CD8+ T-cells: function and response to HIV infection. Curr HIV Res 2:23-37.

Haney M, Gunderson EW, Rabkin J, Hart CL, Vosburg SK, Comer SD, and Foltin RW (2007) Dronabinol and marijuana in HIV-positive marijuana smokers. Caloric intake, mood, and sleep. J Acquir Immune Defic Syndr 45:545-554.

Hardy GA, Sieg SF, Rodriguez B, Jiang W, Asaad R, Lederman MM, and Harding CV (2009) Desensitization to type I interferon in HIV-1 infection correlates with markers of immune activation and disease progression. Blood 113:5497-5505.

Hartling HJ, Jespersen S, Gaardbo JC, Sambleben C, Thorsteinsson K, Gerstoft J, Ullum H, and Nielsen SD (2017) Reduced IL-7R T cell expression and increased plasma sCD127 in late presenting HIV-infected individuals. J Acquir Immune Defic Syndr 74:81-90.

Henriquez JE, Rizzo MD, Schulz MA, Crawford RB, Gulick P, and Kaminski NE (2017) $\Delta$ 9-Tetrahydrocannabinol suppresses secretion of IFN $\alpha$ by plasmacytoid dendritic cells from healthy and HIV-infected individuals. J Acquir Immune Defic Syndr 75:588-596.

Hess KL, Hu X, Lansky A, Mermin J, and Hall HI (2017) Lifetime risk of a diagnosis of HIV infection in the United States. Ann Epidemiol 27:238-243.

Huber JP and Farrar JD (2011) Regulation of effector and memory T-cell functions by type I interferon. Immunology 132:466-474.

Iacob SA, Iacob DG, and Jugulete G (2017) Improving the adherence to antiretroviral therapy, a difficult but essential task for HIV treatment success. Front Pharmacol 8:831.

Kang MC, Park HW, Choi D-H, Choi YW, Park Y, Sung YC, and Lee S-W (2017) Plasmacytoid dendritic cells contribute to the protective immunity induced by intranasal treatment with $\mathrm{Fc}$-fused interleukin-7 against lethal influenza virus infection. Immune Netw 17:343-351.

Karim QA (2017) Current status of the HIV epidemic \& challenges in prevention. Indian J Med Res 146:673-676.

Kelley CF, Kitchen CM, Hunt PW, Rodriguez B, Hecht FM, Kitahata M, Crane HM, Willig J, Mugavero M, Saag M, et al. (2009) Incomplete peripheral CD4+ cell count restoration in HIV-infected patients receiving long-term antiretroviral treatment. Clin Infect Dis 48:787-794.

Kessing CF, Spudich S, Valcour V, Cartwright P, Chalermchai T, Fletcher JL, Takata H, Nichols C, Josey BJ, Slike B, et al. (2017) High number of activated CD8+ $\mathrm{T}$ cells targeting HIV antigens are present in cerebrospinal fluid in acute HIV infection. J Acquir Immune Defic Syndr 75:108-117.

Klein TW, Newton C, and Friedman H (1998) Cannabinoid receptors and immunity. Immunol Today 19:373-381.

Kolumam GA, Thomas S, Thompson LJ, Sprent J, and Murali-Krishna K (2005) Type I interferons act directly on CD8 T cells to allow clonal expansion and memory formation in response to viral infection. J Exp Med 202:637-650.

Koot M, Keet IP, Vos AH, de Goede RE, Roos MTL, Coutinho RA, Miedema F, Schellekens PTA, and Tersmette M (1993) Prognostic value of HIV-1 syncytium inducing phenotype for rate of $\mathrm{CD} 4+$ cell depletion and progression to AIDS. Ann Intern Med 118:681-688.

Kozela E, Pietr M, Juknat A, Rimmerman N, Levy R, and Vogel Z (2010) Cannabinoids $\Delta(9)$-tetrahydrocannabinol and cannabidiol differentially inhibit the lipopolysaccharide-activated NF-kappaB and interferon- $\beta$ /STAT proinflammatory pathways in BV-2 microglial cells. J Biol Chem 285:1616-1626.

Lang KS, Recher M, Navarini AA, Harris NL, Löhning M, Junt T, Probst HC, Hengartner H, and Zinkernagel RM (2005) Inverse correlation between IL-7 receptor expression and CD8 T cell exhaustion during persistent antigen stimulation. Eur J Immunol 35:738-745.

Lapenta C, Santini SM, Proietti E, Rizza P, Logozzi M, Spada M, Parlato S, Fais S, Pitha PM, and Belardelli F (1999) Type I interferon is a powerful inhibitor of in vivo HIV-1 infection and preserves human CD4(+) T cells from virus-induced depletion in SCID mice transplanted with human cells. Virology 263:78-88.

Levy Y, Lacabaratz C, Weiss L, Viard J-P, Goujard C, Lelièvre J-D, Boué F, Molina JM, Rouzioux C, Avettand-Fénoêl V, et al. (2009) Enhanced T cell recovery in HIV-1infected adults through IL-7 treatment. J Clin Invest 119:997-1007.
Lincoln D, Petoumenos K, and Dore GJ; Australian HIV Observational Database (2003) HIV/HBV and HIV/HCV coinfection, and outcomes following highly active antiretroviral therapy. HIV Med 4:241-249.

Lo Y-C, Edidin MA, and Powell JD (2013) Selective activation of antigen-experienced $\mathrm{T}$ cells by anti-CD3 constrained on nanoparticles. J Immunol 191:5107-5114.

MacPherson PA, Fex C, Sanchez-Dardon J, Hawley-Foss N, and Angel JB (2001) Interleukin-7 receptor expression on CD8(+) T cells is reduced in HIV infection and partially restored with effective antiretroviral therapy. J Acquir Immune Defic Syndr 28:454-457.

Marrack P, Kappler J, and Mitchell T (1999) Type I interferons keep activated T cells alive. $J$ Exp Med 189:521-530.

Mazzucchelli R and Durum SK (2007) Interleukin-7 receptor expression: intelligent design. Nat Rev Immunol 7:144-154

Meier A, Chang JJ, Chan ES, Pollard RB, Sidhu HK, Kulkarni S, Wen TF, Lindsay RJ, Orellana L, Mildvan D, et al. (2009) Sex differences in the Toll-like receptormediated response of plasmacytoid dendritic cells to HIV-1. Nat Med 15.955-959.

Nguyen TP, Shukla S, Asaad R, Freeman ML, Lederman MM, Harding CV, and Sieg SF (2016) Responsiveness to IL-7 but not to IFN- $\alpha$ is diminished in CD4+ T cells from treated HIV infected patients who experience poor CD4+ T-cell recovery. AIDS 30:2033-2042.

Oxenius A, Price DA, Easterbrook PJ, O'Callaghan CA, Kelleher AD, Whelan JA Sontag G, Sewell AK, and Phillips RE (2000) Early highly active antiretroviral therapy for acute HIV-1 infection preserves immune function of CD8+ and CD4+ T lymphocytes. Proc Natl Acad Sci USA 97:3382-3387.

Poli G, Orenstein JM, Kinter A, Folks TM, and Fauci AS (1989) Interferon-alpha but not AZT suppresses HIV expression in chronically infected cell lines. Science $\mathbf{2 4 4}$ : 575-577.

Prentiss D, Power R, Balmas G, Tzuang G, and Israelski DM (2004) Patterns of marijuana use among patients with HIV/AIDS followed in a public health care setting. J Acquir Immune Defic Syndr 35:38-45.

Reiss CS (2010) Cannabinoids and viral infections. Pharmaceuticals (Basel) 3: $1873-1886$

Rissoan M-C, Soumelis V, Kadowaki N, Grouard G, Briere F, de Waal Malefyt R, and Liu Y-J (1999) Reciprocal control of T helper cell and dendritic cell differentiation. Science 283:1183-1186.

Rizzo MD, Crawford RB, Henriquez JE, Aldhamen Y, Gulick P, Amalfitano A, and Kaminski NE (2017) HIV-infected cannabis users have lower circulating CD16+ monocytes and IFN- $\gamma$-inducible protein 10 levels compared to non-using HIV patients. AIDS 32:419-429.

Rodriguez B, Lederman MM, Jiang W, Bazdar DA, Gàrate K, Harding CV, and Sieg $\mathrm{SF}$ (2006) Interferon- $\alpha$ differentially rescues CD4 and CD8 T cells from apoptosis in HIV infection. AIDS 20:1379-1389.

Roederer M, Dubs JG, Anderson MT, Raju PA, Herzenberg LA, and Herzenberg LA (1995) CD8 naive T cell counts decrease progressively in HIV-infected adults. $J$ Clin Invest 95:2061-2066.

Roth MD, Tashkin DP, Whittaker KM, Choi R, and Baldwin GC (2005) Tetrahydrocannabinol suppresses immune function and enhances HIV replication in the huPBL-SCID mouse. Life Sci 77:1711-1722.

Sereti I, Dunham RM, Spritzler J, Aga E, Proschan MA, Medvik K, Battaglia CA, Landay AL, Pahwa S, Fischl MA, et al.; ACTG 5214 Study Team (2009) IL-7 administration drives T cell-cycle entry and expansion in HIV-1 infection. Blood 113:6304-6314

Sereti I, Estes JD, Thompson WL, Morcock DR, Fischl MA, Croughs T, Beq S, Lafaye de Micheaux S, Yao MD, Ober A, et al. (2014) Decreases in colonic and systemic inflammation in chronic HIV infection after IL-7 administration. PLoS Pathog 10: e1003890.

Serrano-Villar S, Sainz T, Lee SA, Hunt PW, Sinclair E, Shacklett BL, Ferre AL, Hayes TL, Somsouk M, Hsue PY, et al. (2014) HIV-infected individuals with low CD4/CD8 ratio despite effective antiretroviral therapy exhibit altered $\mathrm{T}$ cell subsets, heightened CD8 + T cell activation, and increased risk of non-AIDS morbidity and mortality. PLoS Pathog 10:e1004078.

Sousa AE, Carneiro J, Meier-Schellersheim M, Grossman Z, and Victorino RM (2002) CD4 $\mathrm{T}$ cell depletion is linked directly to immune activation in the pathogenesis of HIV-1 and HIV-2 but only indirectly to the viral load. J Immunol 169:3400-3406.

Tan JT, Dudl E, LeRoy E, Murray R, Sprent J, Weinberg KI, and Surh CD (2001) IL-7 is critical for homeostatic proliferation and survival of naive T cells. Proc Natl Acad Sci USA 98:8732-8737.

Tanasescu R and Constantinescu CS (2010) Cannabinoids and the immune system an overview. Immunobiology 215:588-597.

Yi JS, Cox MA, and Zajac AJ (2010) T-cell exhaustion: characteristics, causes and conversion. Immunology 129:474-481.

Address correspondence to: Dr. Norbert E. Kaminski, Michigan State University, Institute for Integrative Toxicology, 1129 Farm Lane, Room 165G, Food Safety and Toxicology Building, East Lansing, MI 48824. E-mail: kamins11@msu.edu 